- Language Death. International Journal of the Socid, gy of Language, 12 (1977)

- Language Death. Iinguistics, 191 (1977)

\title{
CHARLES KIEFFER
}

The Approaching End of the Relict South-

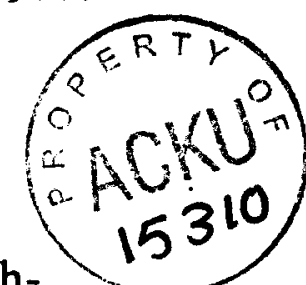
east Iranian Languages Örmuri and Parăči in Afghanistan

INTRODUCTION

On the eastern edge of the Iranian plateau there is a linguistic area remarkable in many respects. It is not only marked by ancient and uninterrupted contacts with Iranian and Indo-Aryan languages and by a multiplicity of languages reflecting the multitude of ethnic groups, but also by the coexistence of three disparate linguistic levels: an ancient level, that of the Kafir ${ }^{1}$ and Dardic ${ }^{2}$ languages, scarcely noticed by the ma icd new arrivals; a second, of which today only two languages are flourish-

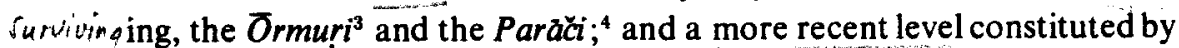
The last arrivals, the Pašto and the Persian languages. ${ }^{5}$

I) As at numerous other points of the Iranian plateau, one is witnessing a progressive reduction in linguistic diversity. Economic growth and political unification are going hand in hand with the elimination of languages which have ceased to be or which did not succeed in becoming local, national, or official languages.

Here as elsewhere one invokes a number of evolutionary phenomena, planned or not. The strengthening of central power, the development of means of communication, the rise of mass media, making the population literate, the intermixing of the population, particularly by the required military service and by the moving of laborers indispensable for the works of public utility, the spontaneous or forced assimilation of the minorities, etc., are also factors of the economic, political, and social framework in which the authoritarian promotion of certain privileged languages and the elimination of others is manifested.

The confines of this article and the nature of our inquiry, essentially devoted to the eastern edge of the Iranian plateau, do not permit us to study this process in its entirety nor at all the points where it has 
appeared in the past and where it manifests itself today. The Iranian world. which includes Iran, Afghanistan, Pakistan, Paštunistan, ${ }^{6}$ and Soviet Tajikistan, covers, in fact, an immense area where about ten languages and about a hundred dialects were and are spoken. ${ }^{7}$ The problems brought up by the linguistic situation are such that it does not seem that a single man can master them: certain of these languages are attested by written documents in about thirty different writing systems and already have a history which goes back 2,500 years; the others in use today, have not yet been completely described.

In the framework of these studies on the theme "language death" we will be content with bringing a concrete testimony illustrating the sociocultural conditions in which two residual languages of the eastern edge of the Iranian plateau are heading toward disappearance, thus putting an end to the existence of the group of Iranian languages called the Southeast group. ${ }^{8}$ These two languages, the $\bar{O}$ rmuri and the Parä̌ri are, in our present state of knowledge, both located south of the line of division of the waters of the Hindukus. In contact with the large local and national languages, the Pašto $^{9}$ and the Persian of Afghanistan or Dari $^{10}$ they are doomed to disappear in the near future. This is at least the conclusion to which we have been led as a consequence of studies carried out on location during recent years. This near end which is already heralded by others as far as $\bar{O} r m u r i$ is concerned, likewise threatens Parä̌ci for other reasons and in other conditions

We will thus try to describe and, insofar as possible, to analyze the respective situations of these two relict languages. G. Morgenstierne, their discoverer, gave a grammatical and lexicological description of them as early as 1929." But in the course of the last fifteen years we have had the occasion to follow his efforts, which permits us to present here, for each of these languages, on the one hand an analysis of its natural environment and of its sociocultural environment and, on the other hand, a study of the process of disappearance in which each of them is engaged in its own way.

For this we will examine all of the information known concerning their past, the essential traits characterizing their present situation, and finally, we will attempt to anticipate the future on the basis of current facts such as appear in the socioeconomic profile of the two multilingual groups doomed to lose their ethnic identity in the near future.

In reality $\bar{O}$ rmuri and Parăči are the only extant Southeast Iranian languages located south of the line of division of the waters of Hindukuš, to the west of the Könar river, to the north of the Käbol river, and to the east of the valley of Sälang, of which the only residual representatives today are $\bar{O}$ rmuri (Orm.) and Parä̌̆i (Par.)

2 The two relict languages of the southeast, occupy two triangular zones with the apexes pointing to each other in the surroundings of Caboul, Par. to the north and Orm. to the south. It is probably there that the two conquering languages, Pașto and Persian, which have become large local and national languages, took them by surprise and displaced them little by little. There may have been other languages, but they are already dead and no traces of them have been preserved. As we can speak of the death only of that which we know, in the case of that which exists, we will speak only of Ormuri and of Paräči while trying to describe their present situation in order to show better how they are dying.

THE SITUATION OF Ōrmuri

$\bar{O}$ rmuri is spoken at two points of the oriental edge of the Iranian plateau. A) In Känigräm, a village of Waziristan south of Pakistan, Orm. šör, literally "the city", where the Wazir also live as well as the Mahsud who all speak Paštō. The $\bar{O}$ rmuri speakers, who nu mber a thousand, designate themselves Barki or Braki (Baraki). Some of them consider themselves as sädät, descendants of the Prophet. All the men are bilingual or trilingual (Ōrmuri, Paștō mahsudi, and Hindkō, which is a variant of Sindhi). Some girls speak only $\bar{O} r m u r i$, but later they all learn Pașto. Ormuri is the maternal and domestic language of an ethnic group which is relatively homogeneous and more important and richer than that of the Mahsud, which is on an equal footing with its neighbors, the Wazir. This dialect $\bar{O}$ rmuri of Känigräm, more archaic, firmly established in a prosperous community where it dominates the other languages, is not understood in Baraki-Barak, in Afghanistan. Moreover relations of the two linguistic groups established on both sides of a political border which is often contested, are practically non-existent. For the concern that interests us we will take into consideration only the language in use in Afghanistan, on the road to extinction.

B) Near Baraki-Barak the government center of the province of Logar, $160 \mathrm{~km}$ by air from Känigräm, in several qala, fortified farms, like Cendăl, Sangtuy, and Nurolläh. In the village of Baraki-Barak ${ }^{12}$ itself Ormuri has almost disappeared already: only a few old people still understand it, a few children know a few words of it (the numbers from 
1 to 10 , father. mother, greetings), but the domestic language is in general a variant of rural Persian, more or less close to Käboli, or sometimes Paș̆ō when the father has married into a Paș̆tun tribe.

One thus only finds real $\bar{O}$ rmuri speaking in the nearby farms, but of the 300 or $400 \bar{O}$ rmur who live there, less than about fifty still speak Ormuri, for the most part adult men or old people who, contrary to the majority, practice strict endogamy. Many of the middle-aged people spoke it in their youth, but scarcely use it any longer, except occasionally, as a secret language, when they do not want to be understood by the Persian or Paștó speakers. The young people, at least some of them, still understand it. but do not speak it. However one of my best informants, who was about twenty in 1968, was left without a father and had continued to speak his tribal language with his elderly mother.

In Baraki-Barak, Ormuri has thus reached the last stage of its resistance. All the $\bar{O}$ rmuri-speakers are at least bilingual and for the most

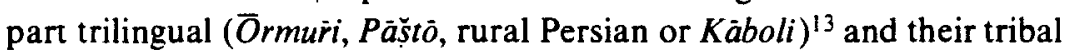
language has no more than a weak function: it is not a local language, nor one of civilisation, it has no written or oral literature, and it no longer serves as a vehicle for any tradition. This suffices to doom it. As soon as the Örmur leaves his farm, his language no longer serves him for anything and on the farm itself, through the play of exogamic marriages, it suffers competition with Pašstō and Persian.

It depends on the objective needs (for example, the obligation to use the language of the Paștun or Tajjek conversational partner) or subjective needs (choice of words or expressions which are borrowed, more adapted to what is meant than those which his mother tongue offers him); the Örmur passes from one language to another, as from one register to another. It is thus inevitable that contact phenomena manifest themselves. We will point out a few to illustrate the linguistic conditions of the death of a language.

For the $\bar{O}$ rmur who is trilingual, neither consideration of aptitude nor of the norm generally intervenes. $\mathrm{He}$ is, properly speaking, a multilingual, fully active in all circumstances; he passes from one language to another to make communication efficient. On the farm he speaks Ormuri with his grandmother, when it concerns the needs of the children, Paštō with his Wardag wife about the field work, and Persian with his children who attend primary school in Baraki-Barak. But two minutes later, because he will have changed the subject, he will address his grandmother in Persian, his wife in Ormuri and his children in Paștō.
If his grandmother has only passive knowledge of Persian and his wife a passive knowledge of $\bar{O}$ rmuri, they will answer in their mother tongue. As for the children, they are forced only to speak Persian and Paș̌to because of the Persian-speaking school and the neighboring Paș̆tuns and have only a latent knowledge of Ormuri. Outside of the farm the $\bar{O} r m u r$ will speak Persian or Paș̆tō again depending on the ethnic origin of his conversation partner, but very rarely Ormuri, even with an Ormuri speaker, because at the bazaar, where one is never alone, it is a serious fault in manners to speak a language which no one understands, and that may only hide bad intentions.

The intrusion of the surrounding local languages into the hearth, the prestige which the radio and teaching gives them, the rapid evolution of the cultural milieu and the economic conditions of which the local languages are the vehicles and witnesses, all these facts converge toward the same result: the more and more restricted employment of the tribal language and, as obligatory corollary, the contamination of it by the local languages. We have not brought up a single example of lexical or syntactic borrowing from Persian or from Paștó to Ōrmuri, as the vocabulary of the latter is taken over by about $90 \%$ by borrowings from Persian and Paș̌to, and its morphosyntactic structure shows striking intrusions of the surrounding local languages.

The linguistic profile of $\bar{O}$ rmuri on the road of regression is characterized by a number of traits, of which we have given details elsewhere. ${ }^{12}$ Let us be content to recall the principal of these, introduced by the multilingualism.

\section{a) The effects of multilingualism on the phonetic level}

One may ascertain first a certain "wavering" in the realisation of several phonemes. Thus we found, with the same informant, for "cow": góp, góy and guy; for "ear": góy and guy; for "excrement": guy. Now the oppositions /gốy/ cow: /góy/ ear: /guy/ excrement were only obtained in the artificial context of an "explication". In fact, if our informants distinguish clearly three types of $/ o /: 1 . \bar{o} 2 . \dot{o}$ and 3. ò (erwọlòk "bring"), as soon as they stop observing themselves, they realize $0 \mathrm{rm}$. $/ \bar{\partial} /$ as Persian $\dot{o}$ and Orm. /ó/ as rural Persian $u=k a ̈ b o l i o$. On the other hand they always distinguish tộs "you" from tus "the ace (in cards)": this opposition is explained by the fact that tộs is originally $\bar{O} r m u r i$ and of a very general usage, while tus is a borrowing from käboli and appears 
only in a very special context, that of an amusement which is somewhat looked down upon, and belongs to a technical terminology.

The $\bar{O}$ rmuri speaker thus has three or even fou r phonological registers at his disposal which interfere when he no longer observes his speech. The four vocalic systems present are the following:

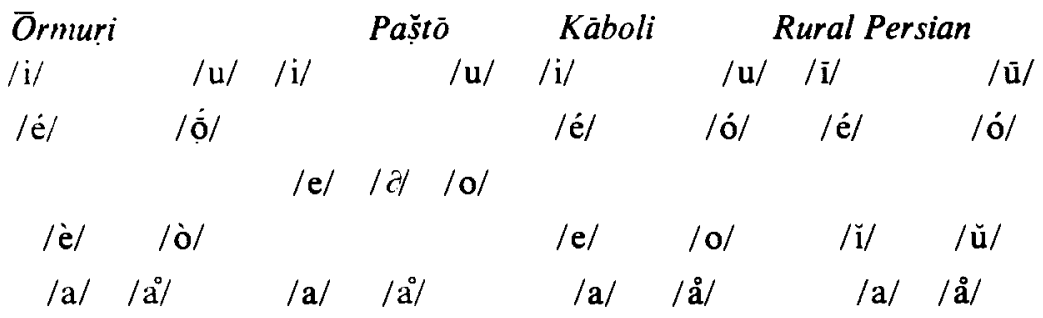

The perfect multilingualism of the majority of the $\overline{\text { Ormuri speakers }}$ permits them, when they observe their speech, to respect, for the words originally Ormuri or considered as such, the phonological system of $\bar{O}$ rmuri and to follow the system of Käboli or rural Persian when it is a matter of borrowings. But when the speaker lets himself go, he passes from one register to another: thus gộy "cow" pronounced with /ó/ Käboli góy; but with the Paṣtó accent he would say ${ }^{*} g o y(\mathrm{ps} s / o /=$ $o / o$ ), which he immediately corrects into guy, which in rural Persian can be interpreted as *güy or *güy. As for the trilogy guy "cow", guy "ear" and guy "excrement", it is necessary to observe here the mark of rural palatisation normally reserved for words of Persian origin.

This multiplicity of registers thus explains the differences which one may observe in the transcription of all those who studied $\bar{O}$ rmuri. In

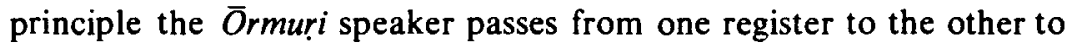
preserve the orignal phonetic cloak of each word. In fact, internal to the spoken chain, this "gymnastics" requires a great effort so that there are numerous "misfires" (intonation of Paș̆tō, of / Käboli as spoken in the city or of rural Persian applied to Ōrmuri words). One could thus say that when they are not observing themselves, the $\bar{O}$ rmuri speakers speak $\bar{O}$ rmuri sometimes with a Käboli accent, sometimes with a rural Persian accent, and sometimes with a Paștō accent. The retreating position of $\bar{O}$ rmuri in relation to other languages would seem very clear, when one observes that it also happens that the $\bar{O} r m u r$ speaks Paștō with a Käboli accent or Käboli with a Paș̆tó accent, but never either of these languages with an $\bar{O}$ rmuri accent.

The differences found in accentuation show exactly the same situation. But the coexistence of three systems of accent create only an apparent disorder. As soon as one says that the speaker of $\bar{O}$ rmuri has suddenly passed from the Paștó register to the Käboli register, everything is in order again, in an order which is perhaps not that of the original Ormuri but that of the language today. Thus the plural guyi (accent on the last syllable) "the ears", for guyi (accent on the penultimate), is explained by the attraction of Käboli gušs( $h)^{\circ}$ (accent on the last syllable) where the mark $-(h) \dot{a}$ attracts the stress, whereas in $\bar{O}$ rmuri the mark $-i$ is enclitic: the subject has passed to the Käboli register.

Summing up, it is a matter of rather banal phenomena of linguistic interference at the level of secondary articulat: $n$. Changes in the realization of the phonemes occasionally lead to a certain perturbation in the phonological system or accentual system of the language with least functions. The characteristics particular to the Käboli or Paștó systems of borrowing are found again in the $\bar{O} r$ muri system of welcoming greetings and determine, when the $\bar{O} r m u r i$-speaking subject lets himself go, what one generally and informally calls a foreign accent; but as it appears in the maternal language, it assigns a dependent status to this language.

\section{b) The effects of multilingualism on the lexicon}

At first glance one recognizes in the $\bar{O}$ rmuri lexicon a considerable number of borrowings from Käboli and a more restricted number from Paštó.

\section{The lexicon particular to $\overline{\text { rmmuri }}$}

The $\bar{O}$ rmuri lexicon appears only in some zones of the maximum resistare. the zones which are the most conservative in vocabulary:

- the ordinal numerical adjectives to 900 , to 70 , to 17 or to 10 , depending on the informants;

- the verbs: around 85 simple verbs with the corresponding causatives in -aw-, for example cir-: cirók "graze" and ceraw-: cerawók "make graze", lip-: lipó́k "suckle" and lapaw-: lapawók "make suckle", etc. - the grammatical morphemes: conjunction $k a$ "that"; prepositions $t a$ "of", pa "by, with"; postpositions $d i$ "of (origin)", $k i$ "to", $(e-$-iné "in", etc.; interrogative particle $k e ́$ "why?" 
- the personal pronouns: 1. $a z$, obl. mun, 2. $t u, 4$. måx, 5. tós.

- the directional pronouns: 1. er-, 2. dar-, 3. al-.

- the demonstratives: of the object approached $a-, k(i) r \dot{e}$, etc.; of the object moved away from $a f o, k(u) f o$, etc.

- the reflexive pronoun $x o ́ y, x u y$.

- the particles of determination: definite article $a$-, indefinite article $\breve{s e}$.

- the indefinites: éc "none", bé "other", ca "some", cun "a certain quantity of", perhaps ar "each".

- the interrogatives: cén "which?", cun "how much?", ké "why?" caki "for what?", kók "who?", goda "where?".

- the verbal morphemes: desinences, mark of the causative, etc.

On the other hand islands of lexemes are preserved, referring to the family, the house, the human body, nature, the stars, rural life, the animal kingdom, time divisions, various utensils, colors, religion and moral feelings.

If all these words are not originally $\bar{O}$ rmuri, they are in any case characteristic of the Örmuri lexicon in relation to that of the surrounding languages. It is the same with the word qalye $t$; considered typically Ormuri by an informant, it presents particular features which make one think of a borrowing; $q$-would indicate a Käboli borrowing or a Turkish borrowing, and $-t$ either a borrowing from Indian via Paștō, or a borrowing from hazäragi Persian, which would seem inconsistent; although in itself it appears indeed to "belong" to the language.

The borrowings are made either from prs, kb, or from pš. The choice between the prs borrowing or the $p \check{s}$ borrowing with the same individual essentially depends on the mother. In fact, the most numerous borrowings are prs or $p \check{s}$ depending on whether the mother is Persian-speaking or Paštun-speaking. If the mother is Örmuri-speaking, of the $\overline{O r m u r}$ tribe or of a dependent tribe (h)amsåya living in symbiosis with the Ormurs, the prs borrowings are in preponderance. It has not been possible for us to make statistical research because of the difficulties of coming into contact with the women (we have, in eight years, been received only in a single Orm. family, that of our informant Sufi Sēr Mómad, where we met his late mother in 1967, his wife, and his daughters), but our explication is confirmed by our informant Xalilullah.

A written language selects, chooses, and rejects, that is to say, creates a norm in unique terms of which the spoken language today is nolonger able to abstract from (compare the phenomenon of dialectal levelling of language following alphabetisation of the rural masses). On the contrary, a language like Ormuri shows the symbiosis of disparate terms, of parallel series of borrowed words, of pronunciations, of different forms and structures, of which the concurrent usage is subject to but one condition - which suffices to harmonize the system - that of mutual comprehension. This superabundance even has the tendency to snowball, for one also needs substitutes to preserve in all circumstances, in all contexts, this mutual comprehension, which is the raison d'être of the language. Hence we may ascertain the coexistence in Ormuri of two

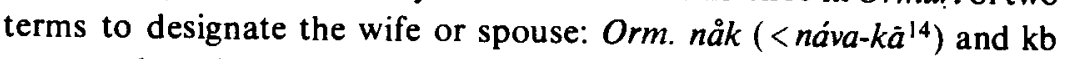
$z a n$; on the other hand that of the homonyms nåk "the wife", and nåk "pear". This homonym is not embarassing for the speaker - the situations and contexts being in general quite different - nåk "wife" is not about to give way to $z a n$, for it is part of the pair måli-nåk husband-wife and zan far from being on the way of supplanting it is only an occasional substitute, appearing only:

- with speakers rarely speaking $\bar{O}$ rmuri with whom the original lexical stock is becoming hazier and hazier;

- in the compound borrowed from kb pir-zan.

- it remains finally to the disposition of the Ormuri speaker to permit him to escape the wife-pear ambiguity; now these cases are extremely rare, all the more so since there are scarcely pear trees in Logar. Finally, in spite of the entries zan "wife" and nåk "pear" which figure in our lexicon by force of circumstances - because we heard them ! these words don't have any real existence in the $\bar{O}$ rmuri language, but only in the latent vocabulary of the multilingual $\overline{\text { Ormur. Contrary to }}$ what we thought at first, the $\bar{O}$ rmuri speakers are in general perfectly conscious of the differing status which they assign to different elements of their vocabulary: thus zan "wife", and nåk "pear" are declared to be Persian.

Putting aside the list which we gave above, all the rest of the vocabulary is constituted of words belonging to the lexicon of Paștō and still more of Persian. If one will admit the distinction between borrowing and lexical substitution, we must note that native borrowing is relatively rare. In fact, it is more often a matter of procedure of lexical substitution; substitution, which is typically the case for multilinguals, presents a lesser adaptation, and the substitute, as we confirmed, conserves the phonological system and the accentuation of the original language. This is confirmed by the fact that the $\bar{O}$ rmuri speaker is conscious of employing a word of another language and of introducing into the spoken utterance a heterogeneous element of which he in general knows the origin. The case of qalyet cited above is revealing in this regard: $\bar{O}$ rmuri 
is all that is neither Persian nor Paṣ̆to; the rule is valid in the majority of cases.

Mechanism of borrowing and of loan translating nominal phrase. As far as the facts of contact due to multilingualism are concerned, another distinction is more interesting, that of borrowing and of calquing above all when it is a matter of a phrase.

Let us take the case of "black pepper" in very popular use. We have three expressions:

a) morč-e siyå, a pure and simple borrowing of the Käboli phrase;

b) morč-e yras, a hybrid calque, which preserves the syntactic structure of its source (determined substantive $+e z \bar{a} a f e+$ determining adjective), which borrows the term morč for which there is no Örmuri equivalent, and which translates the adjective "black";

c) vras morč, a perfect calque, which presents the syntactic structure peculiar to $\bar{O}$ rmuri (determining adjective-determined substantive), which borrows the term morc.

We are observing here the intrusion of ezäfe in $\bar{O} r m u r i$ where it however remains "outside of the system".

The case of the expression "holiday" will confirm this, by the incoherence of even form $b$ ):

a) ruz-e id, pure and simple borrowing of the Käboli phrase;

b) ta-id-e ruz, incoherent calque, where the mark of connection peculiar to Ormuri (preposition ta de) coexists with that which is peculiar to Persian (ezāfe -e);

c) ta id a-ruz, phrase peculiar to $\bar{O}$ rmuri which there is no reason to consider as a calque, where $a$-represents the actualizer (a sort of definite article) = "the holiday"; it is the key to phrase b).

In fact, in the phrase b) the speaker who is influenced by the Käboli phrase a) which is present in his mind at the same time as the phrase c) which is peculiar to $\bar{O}$ rmuri, makes a kind of a syntactic error of combination (pataques) which is not far from being a lapse; a lapse revealing, however, the pressure which the common language exerts on the domestic language, and of the foreign character of the Persian ezáfe, to which even the structure of $\bar{O}$ rmuri is refractory.

The following five variants are attested for example for "stick":

a) čub-e dest, pure and simple borrowing from $\mathrm{kb}$, literally handstick; prs order: determined-determining; b) gon-e dest, hybrid calque: translation of the first element, preservation of ezäfe and of the second element; prs order: determined-determining;

c) ta dest $e \check{c u b}$, aberrant calque, a true syntactic error of combination (pataquès), due to the introduction of Orm. order: preposition of the genitive $t a$-determining-aberrant and redundant preservation of ezäfe - determined (rare);

d) ta dest-e gón, aberrant calque, translation of the first element; $\bar{O}$ rmuri order as in c) (frequent);

e) ta dest a-gón, perfect calque; $O r m$. order: determined-determining: Preposition (gen-) + substantive ${ }^{1}+$ art. + subst. ${ }^{2}$

In c) and d) it is the confusion of ezâfe-e and of the article $a$-of $\bar{O} r m u r i$, the one an enclitic and the other a proclitic, both placed at the junction of two elements (determining-determined) of the phrase, which favors thesyntactic error of combination (pataquès): the speaker, as happens frequently with the multilinguals, has not completely adopted the register of either one or the other language. It is a psychological problem (with one's attention insufficiently fixed) or sometimes even a pathological problem (a slowdown in mental function in people with arteriosclerosis): it is generally sufficient to get the attention of the subject for him to correct himself. However if one asks for explanations about his "error", he is generally disturbed; in fact, he is not clearly aware of the diverse structures of the nominal phrase in prs and in Orm. and quite naturally trusts to his linguistic habits which he would not be able to analyze.

Processes of lexical substitution. Lexical substitution is very different from borrowing which is more or less phonetically adapted and integrated into the language to the point that the speaker considers it like an original word. It has the following characteristics:

1) the phonetic and accentual adaptation is less than in borrowing; very often it is even non-existent: the form preserves the features of the phonological and accentual systems of the language of origin and, in the case of a phrase, its syntactic structure:

\begin{tabular}{llllll} 
& & \multicolumn{3}{c}{ substitution } & \multicolumn{2}{c}{ borrowing } \\
$\mathrm{kb}$ & lóla & 'tube' & lóla & lóla & $(o ́$ \\
pš & monj & 'dwarf palm' moj & munj & $(u !)$ \\
$\mathrm{kb}$ & mobå & 'choléra' & mobå & mubå & $((u !)$
\end{tabular}


róz-e id/t 'religious holiday' 'black pepper' kb morč-e siyå
1 harles Kieffer

ruz-e it

rọz-e it

rọ́ž-e it

rọ́z ta it

rọ́ž ta it, etc.

murč-e siyå

murč-e siyā, etc.

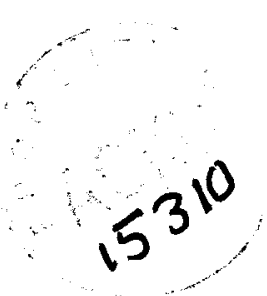

r
2) the speaker is immediately conscious of employing a word of another language, he is conscious of carrying out a substitution and, in general, inclined to give a form or an equivalent phrase in $\bar{O} r m$ :

orm: by substitution >

orm: original

róz-e id/t

ta id a-ruz/róz/rộz

morc̆-e siyå

y råmořc/murč/murč

Several intermediary stages are possible, depending on the register adopted by the speaker:

kb róz-e id/t $>$ rural Dari $=$ pure and simple $\bar{O}$ rmuri borrowing ruz-e $i d / t>\bar{O}$ rmuri hybrid calque $t a$ id-e ruz/róz/róž (coexistence of the mark of connection peculiar to orm: ta, and that of prs: ezāfe -e) >

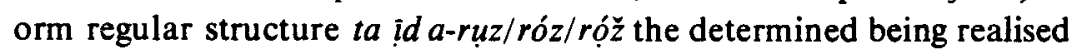
by the particle $a$, sometimes confused with $e z \bar{a} f e-e$ !). ${ }^{15}$

3) lexical substitution is done by multilingual subjects, at least at the beginning. Later it may be propagated by groups which are not multilingual. It is then that the process of borrowing is introduced: the word or the phrase is pronounced with an $\bar{O}$ rmuri accent and intonation and it then undergoes phonetic and accentual adaptation which makes a borrowing of it.

4) this adaptation is not necessarily the same at the level of the word and of the phrase, it is not strictly parallel: sometimes the word is already perfectly adapted, whereas the syntactic structure of the phrase remains hybrid:

ex. ta id-e rọ̆ž (where rọ́ž is orm)

sometimes the syntactic structure of the phrase is perfectly regular, whereas, on the phonetic level, the determined remains a pure and simple borrowing:

ex. ta id a-ruz (where ruz is a borrowing not adapted from rural Dari) 5) the determination of the register adopted by the speaker does not belong to the task of the linguist, properly speaking. As in all cases where
Iranian Languages imuri and Paraxi in Afghanistan

this notion of "register" comes in (phonetic interferences of orm-kbrural Dari- pš, accentual interferences, strict preservation of thepersonal values of the directional pronouns or the tendency to use al-in particular, the use of tenses/modalities, etc.), the essential factors to consider are psychological (liveliness of the mind - slowness of the mind, attentiondistraction), social (social origin, intellectual level), etc., and belonging to ethnolinguistics, psycholinguistics, and sociolinguistics.

\section{c) The effects of multilingualism on the syntactic level}

It is not the same with all the syntactic structures peculiar to Persian. Two examples of interference are particularly striking.

1. Actualisation of the object. It is rendered in Persian by the enclitic particle -rā (ketāb-rā mixaram "I buy the book in question") whereas in Paș̆tõ the context alone permits one to determine the distinction between an actualised object or not (ketäb perram "I buy a book/the book in question"). In Ormuri the situation is more complex. In Kånigråm we found for example: $a-b u z-e m$ dye $k$ "I saw the goat (in question)" but the actualiser $a$ - appeared in any phrase at all - subject, object, or prepositional. Now the Ormuri-speakers of Baraki-Barak, bilingual for a long time (Örmuri-Persian), feeling the need to mark the actualised object by an appropriate morpheme, in the manner of Persian -rā, has carried out an outright functional transposition of the preposition $k u$ (in relation to a postposition: $k u$ mun $k i$ "to me") in the proclitic actualiser of the object, and he says today ku boz-am dék "I saw the goat (in question)". Thus we have the opposition $k u$. . ki preposition + postposition = " to": $k u$ alone $=$ prs $-r a \overline{.}$. Every time that the Persian speaker of Caboul or of Lögar uses $-r \bar{a}$ in a given context (pop. - $a$ after consonant or -ra after a vowel), the Ormuri speaker uses proclitic ku-: yåsp bu nål kam "I shoe a horse", but ku yåsp bu nål kam "I shoe the horse"; spók ku adbu cat ke "the dog licks the bone" (and not "a bone"); ta kirži ku wólk-at pråke? "have you sold the eggs?"; zambur kumun gezawók "the wasp stung me" $(k u$ mun $=$ Persian $m a-r a ̄)$, etc.

2. Possessive Construction. In the $\bar{O}$ rmuri of Baraki-Barak the competition between three structures of the possessive (passive) construction constitutes a surprising fact. If we compare them with the parallel constructions in use in the Käboli or Paștō languages we obtain the following table, for example for the sentence "I took a knife":

a) orm. c̆åku-malgóstok $=\mathrm{pṣ} \quad \check{c}$ āku mē wēwor 
b) orm. az čåku alalgóstok = pṣ mā čāku wēwor

cf. kb man čåqu bord-am

c) orm. čåku algóstok-am $=\mathrm{kb}$ čåu bord-am

Paštō gives us the key to the semantic difference between a) "I took a knife" and b) "me, I took a knife", and also to the difference in structure between the possessive construction in Pașto and in $\bar{O} r m u r i$ :

a) orm. = pš: object + personal enclitic + verb in the past

b) orm.: personal pronoun subject case + object + verb in the past

pš: personal pronoun object case + object + verb in the past

The structure is the same is $\bar{O} r m u r i$ and in Pašto, except for one point: Paštō preserves the agentitive (oblique case of the personal pronoun) while $\bar{O}$ rmuri has replaced it by the direct case (subject case of the personal pronoun). We thus remain in the norm of the possessive construction, except as concerns the abandonment of the agentitive by Örmuri.

The construction c), on the other hand, is "monstrous" with reference at least to the possessive construction as it is provided to us by the tradition of Iranian languages of the Oriental group. But the identity of the structures of the $\bar{O}$ rmuri sentence and of the same Käboli sentence: object + radical past of the verb + personal desinence, shows clearly the process of syntactic calque in which $\bar{O}$ rmuri is engaged.

However, it is now necessary to make clear that this aberrant construction is relatively rare, that it is more a bilingual lapse, than a living structure established in the language, and that our informants often recognized it as an "error".

These few examples of contamination of $\bar{O}$ rmuri by the surrounding koinès show first of all that the true language of communication of the multilingual $\bar{O}$ rmurs - and they are all multilingual - is above all Käboli Persian, and secondarily Pașto. They indicate contact then, at least in the course of the past centuries, more important with Persian than with Pașto, for the deepest contaminations, those that even touch the syntax, show the Persian structural model; but they also confirm that the grammatical mechanism of a language on the path to extinction, if it is touched by the contamination, is not, properly speaking, perturbed, since the communication is completely preserved. The facts of contact of languages are not then involved in the process if one wants to analyze the reasons for which $\bar{O}$ rmuri is on the point of being no longer spoken: neither the borrowed vocabulary, nor the phonological or accentual perturbations, nor even the syntactic contaminations obscure comprehension; on the other hand, Ormuri is not disappearing as a consequence of a phenomenon of mixing of languages to the extent that the multilingual Ormurs would basically only know one language in two or three modes of expression. They are not speaking a language mixed three ways, of which they use sometimes the one, sometimes the other, and sometimes the third. They are speaking three languages, their own,

Káboli and $P a s ̦ t o$, , and if the young people generally have already or are going to abandon $\bar{O}$ rmuri, it is simply because it serves no purpose for them any longer.

\section{d) Survival of Ōrmuri and the ethnic identity of the Örmurs}

If the impending disappearance of $\bar{O}$ rmuri does not leave any room for doubt, its survival, on the other hand, poses a problem which has perhaps not been emphasized enough. It is, indeed, extraordinary. At first glance there is indeed no reason for this language to have survived.

The geographic situation of Baraki-Barak, ${ }^{16}$ far from being an isolated area, cut off from large through-roads of communication and from agglomerations of Paș̆to speakers and Persian speakers by natural obstacles, would favor on the contrary contacts with the large common languages and in this way favor the disappearance of $\overline{\text { rmuri. Baraki- }}$ Barak is an agglomeration established in an open valley, situated on an important connection road uniting the large through-roads CaboulGhazni and Caboul-Gardèz, at the beginning of a passable road which, through Patxao-e Rōjani and Baraki-Răjan, permits one to reach directly either Gardèz, or Carx-e Lögar and even Ghazni. It therefore cannot be a matter of a hidden linguistic pocket as is the case for example in Sotal where the Parăči language (v. infra) is in danger only since 1969, i.e., since the construction of a road broke its isolation.

The situation of the $\bar{O}$ rmur clan in the tribal hierarchy of the region of Baraki-Barak does not permit one to assume it to be a prestige language either. The $\bar{O}$ rmurs occupy only a modest third rank after the Paštun and the Täjek, just before the Hazära and, of course, the Hendu and the $\breve{J} a t$. Very often, depending on their matrimonial arrangements or depending on the ethnic origin of the speaker, they declare themselves at first to be either Paštun or Tăjek, an assimilation rendered plausible by their trilingualism. On the other hand, numerically, these few hundreds of Örmurs have no weight beside the thousands of Paștuns and the 
Tajeks who surround them on all sides. Thus, neither the numerical significance of the speakers, nor the tribal prestige, nor its geographic location can explain the survival of a language which is - is it necessary to say it? - neither national nor official nor common. Moreover, with its vocabulary taken over by about $90 \%$ borrowings, with a syntax bearing the stigma of foreign contact, it is obviously engaged in an irreversible process of contamination.

There could remain a religious motivation. At first glance this hypothesis would appear difficult to maintain: the Ōrmurs consider themselves and are considered by the other clans as irreproachable Sunnites; moreover, we can testify that they observe more rigorously than most of their Paštun or Tajek neighbors the religious rules concerning prayer, fasting, and the prohibition of alcoholic beverages. In fact nothing distinguishes them from the Moslems practicing strict observance who live in the surrounding area. At first glance it would thus appear that the Örmurs, not constituting a sect by themselves, do not have any religious reason for preserving their clan language.

However as early as 1927, G. Morgenstierne ${ }^{17}$ had put forth the hypo? thesis that they had remained Zoroastrian until a relatively recent epoch: in fact, $\bar{O}$ rmuri is the only Iranian dialect which has preserved in its dialect a technical term of Zoroastrianism for "study, read": in BarakiBarak (h)aw-: (h)awók, in Känigrära aw-: iș̆tak (cf. av. aiwi-ah-). On the other hand, it is very possible that the heretical tendencies of Báyazid Anșari (1525-1572), ${ }^{18}$ an Ormur, may have found a support in the religious traditions and the religious practices of his clan, unless Bāyazid inspired them.

For a long time our quest remained in vain. However, after many years one of our informants gave us his impression that "earlier the Örmurs had been the adepts of a different sect". Which one? "Perhaps they were Shiites ... or sayyed-e xăs ${ }^{19}$ (true descendents of the Prophet)." As or Bäyazid Ansări, overcoming apparent embarrassment, he confessed to us: "All the Ōrmurs know and revere the Pir-e Rōšān ("the saint of the light") and Pir-e Rōsāan az ro'asã-ye mažhabi-ye mà-st ("Pir-e Rōsān is one of the chiefs of our religion").

On the other hand, a certain number of popular beliefs make the Ormurs a different clan than the others, without their being able to support positively the hypothesis of an ancient acceptance of the rōšäniyya heresy: ${ }^{20}$

- it is sum, "of bad sign", to let eggs be hatched by their chickens;

- it is šum to wear clothing of the green clover šaftali color
- to give the first milk of a mother-cow $z o ̣ k$ to someone who is not Ormur: the donor runs a risk of dying or at least of becoming blind and the thief, originating from another clan, would become blind;

- the $\bar{O}$ rmur women never have themselves tatooed on their forehead with $x a ̊ l$, "birth mark, tatoo on the forehead", for they risk dying at the peak of their life.

Summing up, the $\bar{O}$ rmurs are conscious of not being a clan like the others, of having particular popular beliefs, of having a religious past different from that of surrounding ethnic groups, without being able (or without daring?) to make the exact nature of this precise. The criticism of these facts considered individually would be easy: every clan, above all when it has a language sui generis, has the impression of not being like the others; every ethnic group has customs and beliefs of a special kind; everywhere in Islam territory, one supposes, without liking to talk about it, that "earlier" there was another religion. What is necessary to retain of it? Above all, it is suitable to note a disturbing convergence: the $\bar{O}$ rmurs on the one hand appear to be well aware of having belonged in the Islam epoch to a non-Sunnite sect, and advance the hypothesis of Shiitism; on the other hand, the veneration with which they surround Bäyazid Ansäri orients us toward the rōsañiyya. There is no contradiction here: in fact, we know that Shiitism has served as a screen for the adepts of Pir-e Röšän; it is, for example, the case of the Turi ${ }^{21}$ which today constitutes the only case of a Paștun which is completely Shiite. On the contrary, we have no argument at all, either positive or negative, about anything concerning the hypothesis of a Zoroastrian substratum.

If it is correct that the $\bar{O}$ rmurs belonged earlier to the rōsaniyya and that their clan language might have played the role of a religious language or of a secret language, the return of the $\bar{O}$ rmur clan into the ars of the Sunnite orthodoxy has abolished this particular function of $\bar{O}$ rmuri and constitutes the deeper reason for its impending disappearance in bringing confirmation that it no longer serves any purpose for anything.

THE SITUATION OF PARĀČI

Parāc̆i is spoken in three valleys on the South slope of the Hindukuš:

a) in the valley of $\breve{S}$ otol

b) in the valley of Gočulān, region of Nejrao $(-\bar{a} b)$

c) in the valley of Pačay ăn, region of Nejrao $(-\bar{a} b)$. 
Linguistic situation

At first glance one has the impression of great stability. Paräči seems solidly stuck to the ethnic group which speaks it, and the Parăči seem very attached to it. They all understand and speak their tribal language, which is not always the case in a multi-national country: the $\bar{O}$ rmurs of the very village of Baraki-Barak (Lōgar), many of the Nurzi Paștuns of West Afghanistan, the Baluč emigrated to the North, much of the någelin population displaced for various reasons, etc., have adopted a neighboring koiné. The Paräčcis speak their language fluently and employ it not only at home, but also in their relations with the other Paräc̆is. In the valley of Pačayan they speak Paräči even with the Pašais of whom they never learn the language although the opposite is often the case.

This puts us on the track of the place occupied by Parä $\bar{c} i$ in the hierarchy of languages. Śotol, Gočulän, and Pačayàn are "closed" valleys, that is to say occupied by the Paräčis, all of them bilingual in Paräči/Persian (of the köhestäni type), and by Persians speakers (of the Kóhestäni type), who are used to an ancient coexistence to the point that their social structure in clans and sub-clans is strictly identical, the second being only in part the Parăčis who have abandoned their tribal language for reasons not yet well understood. The only regular relations they have outside of their valley are commercial ones, first of all with Persian-speakers (Köhestan, Andarāb, Sälang and Panj̄sēer for the Paräčcis of Šsotol, valley of Ghayn and Bäzär-e Badaxši for those of Pačayān). Their perfect bilingualism excludes on both sides all value judgement on the language of the ones or the others and all recourse to a linguistic hierarchy. Then, when they have relationships with the linguistic groups other than the Persian-speakers, with the Paštuns present in Köhdāman, in Golbāhār, $\breve{S} \bar{x}$, the low valley of Pačayān, Tagao, etc., it is a matter of episodic contacts, commercial interests, interests on both sides, and not of ethnic contacts: each one makes an effort to speak badly the language of the other, the rest being done with the language of gestures; when the business is concluded, each returns to his side. As for the Pašai and the Kafir above all, the moving apart of their established places is such that the question of an ethnic or linguistic hierarchy has no current meaning for the Paräc̆i-speakers of $\breve{S}$ otol and of Gočulàn.

In the valley of Pačayan on the other hand, the situation is completely different. There the Paräčis are in direct and constant contact with two ethnic groups, two linguistic communities which are very unlike, with whom they are forced to establish a modus vivendi, and with whom they are forced to compromise daily. At the bottom of the valley, they border on the Pass̆tun, who take away a few furrows of land from their neighbors every year: they have to defend themselves and as the Paștuns do not think about learning Parăči, it is the Parāči-speakers who learn Paș̆to, recognizing in this way a linguistic and ethnic superiority, by which they try to limit the economic and political consequences ; as much as possible.

Higher in the valley, the Paräči-speaking area is interrupted by the Pašai establishments of Gawrukasăt, Kandi, etc. As often happens, the Pašais are established in the narrowest part and consequently the most difficult part of the valley to cultivate; downstream, the Päräčis have larger and more numerous terraces; upstream they occupy, beyond the moraine deposits, the large and flat bottom of the glacial valley which offers them not only real fields, but also prairies which permit them to carry on animal husbandry. This economically privileged situation favors, as an obligatory corollary, the position of the Paräčis relative to the Pašais: the Pašais are forced to speak, outside of their tribal language, Parāči, Persian and Paștō, whereas the Parāčis, not having any need to know Pašai, learn only Paș̆ó. As for Persian, they speak it, like all the other Paräšis, from birth, concurrently with their mother tongue.

Study of the environment

The very diversity of the economic conditions which characterise the Paräči-speaking valleys, leads us, in order to judge the future of Parä $\breve{c} i$, to analyse the natural and social environment of each one among them.

In $\underline{\text { Sotol }}$ agriculture is predominant, so that these are the difficulties which mark the fate of Paräči. Up to 1960 meter altitude they practice two annual cultures, very often that of the grain ganom, then that of the rice zitayi, but also of other grains yalabāb; then the oil-rich xóräkabāb, above all the colza šaršam. They make very little feed here: a little clover savtal, contenting themselves with gathering wild herbs, in particular a variety of heracleum estuf. Higher up, there is annual alternation, generally, grain one year and corn the following year. In 1973, in Estufälö for example, they harvested corn.

These cultures are made on terraces, yanir, contained inside stone 
walls (<*awa-antarya-, cf. av. ava-antara-). But these terraces are often too small, always threatened by mountain torrents sél which destroy everything in their path, and, in a general way, offer a cultivable surface which is at best very insufficient. Of course, there are almost non-arable plots of land, bóra. Summing up, the valley of Sotol, which does not even produce enough grain and rice, is also short of feed, milk, and meat. To alleviate these shortcomings, the $\breve{S}$ otolis have dangerously developed the raising of goats. As there is not enough pasture, they send them into the mountains, dhar, where they eat all the young scions and contribute to deforestation. Furthermore, the sel mountain torrents are more and more numerous and destroy more and more terraces, ever lessening the surface of cultivable land.

Another consequence of this impoverishment of an ethnic group which is above all agricultural touches the forest economy. In this essentially mountainous region, the wooded vegetation played a predominant role, at least as long as the deforestation was not an important factor. As far as the past is concerned, the preserving of the names of trees in Parăči bears witness to this preponderance of wooded vegetation, wild as well as cultivated: the walnut tree, dežce, the mulberry tree, $t \bar{i}$ (with its numerous varieties), the willow, $y i$, the hackberry, to $\ddot{\gamma}$, the oak (Quercus Ballota), yan, and above all the wild almond tree, bådöm-e dhäri, are utilised from the top to the roots. Unfortunately the abuse of their exploitation has led to a thinning out which borders on deforestation and finally contributes to the incessant nibbling away of cultivable land.

One cannot expect otherwise. Thirty years ago, hundreds of riding horses, $\ddot{\partial} s p$, pack-horses, yåbu, and donkeys, khör, still assured communication with the valleys and the adjacent regions of Köhestän, Peñ̌sèr, Andaräb, and Sälang. We have heard the extraordinary narration of the bozkaši calvary battles, for the possession of a goat, which one organised on the occasion of a wedding, tuy, or other festivities. Today one no longer finds a single horse, and only a small and diminishing number of donkeys assure transport to the inside of the village or the valley. Earlier they went shopping where it was the least expensive for the food and fodder which they needed, in Andaräb or in Golbahär. Today everyone is dependent on the transporters and traders of $\breve{C a} r i k a ̈ r$, of Kaboul, or elsewhere, and the traders' system of credit causes one to buy the most expensive products, alienating by debt most of the Sotoli and eliminating bit by bit the last small proprietors. Thus more and more a rural proletariat develops, most often a true "Lumpenproletariat" of which the subsistence minimum is no longer assured.
If the old people accept this situation - they are forced to, indeed, what else could they do? - the young react by fleeing to the city, to Golbahär, Čărikär, Bagräm, Kaboul, etc., where the factories, the large public works (dams, airports), the army, administration, or small commerce offer to each the chance to carve out his own future.

On the psychological level this process of fleeing - for one flees Śotol like a sinking ship - naturally has a significant counterpart: the young despise the old people stupidly holding on to their crumbling terraces, and they refuse to continue speaking Paräči. It is the language of a homeland which they abhor. It is also the language for which they are mocked in the city. Elsewhere they show the same horror of speaking Köhestāni Persian, as soon as they approach Kaboul, as soon as they work somewhere where it is in good taste to speak Käboli. This attitude has multiple consequences. First of all the family cell as well as the large family are considerably shaken, the old virtue of respect towards one's parents and old people disappears. Śotol is the only place in Afghanistan where I saw a son hit his father to force him to give him a jacket received as a gift. On the other hand, these young emigrants often leave their wives and their children at the village, but when they return "for a visit", their arrogance knows no bounds. Above all they refuse all that is tradition and so too the language: "Your linguistic research in this valley is completely stupid," one of them told me. "Listen, Mistar, 'Mister', there are only three languages in Afghanistan: Paș̆ō which the Paș̆tuns speak, Persian of Kaboul which all the other Afghans must speak, and lazemi (a sort of pidgin which the merchants, the artisans and all those in contact with foreigners speak and are spoken to by the foreigners) which the foreigners speak." Indeed, he never consented to speaking to me in Káboli Persian, the language in which I conversed with all the other inhabitants of the village.

This dislocation of institutions, customs, and traditional values is going to accelerate among the young and still younger established outside of their valley of origin. They want "everything and immediately" and establish a system of dispute limited to immediate betterment of their standard of living. But insufficiently brought up and educated, they are moving rapidly into the "Lumpenproletariat" of the urban society, of which only the most negative aspects are important to them.

What is then the fate of Parāăci in Šsotol? The tribal language of Paräc̆i seems indeed condemned. Those who have emigrated refuse to speak it, and, living scattered in the midst of Persian-speakers and of Paș̌tóspeakers, their children will soon have ceased understanding it. Those 
who remain, for the most part old people, will disappear faster and faster. With the departure of the young, the restoration of the terraces is becoming more and more difficult and rare: their number is diminishing, they are going to nourish less and less Parăči farmers and sedentary people. But in the vicious circle of impoverishment, there are always people poorer than oneself: Šotol will soon see those famished năqelin : appear with their herds of sheep or goats to destroy the last clumps of greenery, perhaps practicing here or there some rain culture, lalmi. If they become sedentary someday and succeed in restoring, with the faith of new sedentary people, the best exposed terraces, then one will hear Paș̆tō spoken.

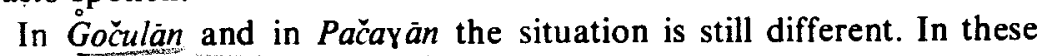
two valleys we were struck by an aspect which we were not able to study elsewhere in Afghanistan, that of a system practically selfsufficient from an agricultural and economic point of view: the Parăči, following an ancient tradition, at least it seems so to us, produce all that they need, grain and rice, substances containing oil, flax for weaving, and the ground berries of the mulberry tree (talxän in Kaboul) replace sugar in their diet. The nuts, dežé, which one sells only when the currency rate is favorable, suffice for the purchase of luxury products which one uses by way of exception on the occasion of celebrations or at the homes of the richest proprietors. But this is an unstable equilibrium: a drought, an economic collapse at the national level, a few bad harvests, a sinking of currency rates, could suddenly knock down their standard of living and accentuate their needs. Then a process will take place similar to that in process in $\check{S}$ otol. A complete reversal will occur sooner or later in a country developing like Afghanistan: the most outlying and self-sufficient valleys are touched only by a more or less important delay. It would perhaps be up to the economists to collaborate with the dialectologist to foresee and prepare a reconversion and prevent a decay.

The cultural environment of the Paräc̆i, like that of the Kafirs and the Pašai, their neighbors, has been subjected to two types of upheavals which have affected the very roots of their traditions and their original mode of life. These are islamisation and technological evolution. ${ }^{22}$

Islamisation is already rather ancient in the Western part of that geographic and cultural entity which constitutes "Grand Nurestān". ${ }^{23}$ We know for example that in 1582 Darwèšs Mohammad Khän-e Ghäzi conducted a Mohammedanian crusade against the pagan population of the "66 valleys", going from Darunta (near Jaläläbäd), to Laymän and
Alingär, Tagāb, Nĕ̈räb and Pačaghän. It is more recent in its Oriental part where Emir Abdur Rahman introduced islam only in 1895-96, transforming Käferestän into Nurestan by fire and sword. It is there, moreover, that one can better study the process of islamisation.

The new faith imposed upon the new converts a model of Mohammedanian life of the urban kind, such as conceived in Caboul. It is characterised by the strict observance of various prohibitions concerning food, women, the whole domain of haräm, ${ }^{24}$ and, as an obligatory 17 corollary, by the adoption of beliefs and new practices: jen(d), "evil spirit", róza, "fasting", nemàz, "ritual prayer", and parda, ${ }^{25}$ "curtain suspended in front of a door or a window", which symbolizes all the secret means of all sexual ethic, both liberal in its principles and rigourous in social reality.

This forced acculturisation dissociated itself from a traditional cultural base, but the beliefs recently adopted are always difficult to analyze by a believer of a more or less recent time, for he remains a neophyte, whereas the others remember his pre-Mohanmedanian religious past. In the end he can only assume this past in renouncing it and is thus not in the process of directly giving valuable information.

On the contrary the analysis of the Parăči vocabulary (but one could also do it for the Darde or the Kafir), always brings all sorts of interesting evidence. The Persian origin, and more exactly Käboli origin, of recent borrowings is also that of islamisation. This testifies to the sociocultural status of the very process of acculturation: the Jacobinian and centralised path by which the spiritual masters in Kaboul, by the mediation of their language (Persian), and in the name of their faith (islam), without worrying about their aspirations, impose on the parăčí proselytes their own "Weltanschauung". From this process of one-way acculturation these lexical islands have come forth ceaselessly growing, completely Persian, the analysis of which reveals the continuous progression of an extraneous influence in the domain of the spiritual culture as well as the material culture. We will restrict ourselves to a few examples.

a) The three compound words 1) ruygir, 2) ruypōss, and 3) ruypot seem, at first glance, to constitute a triad of which the function would be to rank women - for it is only to women that these words can apply -into three social groups according to criteria of decency or increasing prudery. Indeed, undeniably formal characteristics suggest their coming together; they are all three formed from ruy, face - a suffixed determiner: 
1. ruy- + -gir < gereftan "take away", = lit. "he who uncovers his face",

2. $r u y-+-p \bar{o} \check{s}<$ pōšidan "cover", = lit. "he who covers his face",

3. $r u y-+-$ pot $<\mathrm{kb}$ pot $/ \mathrm{t} \mathrm{kadan}^{26}$ "hide", = lit. "he who hides his face".

If we would stop with the analysis of this triad at this level, one could justly assume a state of society where a certain amount of initiative is left, if not to the women, then at least to the heads of the family. Thus certain women would be able to uncover or to hide their face, or, at least, certain heads of the family would be able to grant to the wives of their household a more or less extensive liberty in their apparel and bearing. Of course it is not so.

A first indication appears on the formal level: the suffixed element -pot, an adjective and element of the compound verb pot kadan, is opposed to -gir and pōs, radicals of the simple verbs gereftan and pōšidan. Ruypot would seem to be nothing other than an analogical formation created on the model of the two other terms.

In fact only an analysis of the social classes existing within the Parăč linguistic group and their economic situation can give us hints about the exact sense of these three terms.

The first two contrast two social groups which one finds everywhere in the Afghan countryside:

1) that where the woman has her face uncovered, ruygir, at home, that is, before the members of the family authorised to see her: all the women, those in her direct line of descent, the uncles, likewise the cousins received at home, the servants, and some friends associated with the master of the house by relations of respect like those which unite children to parents (apprentices, pupils, disciples), sisters and brothers (friends), etc. Before all others, at home and outside the home, the woman wears the type of veil in use in the ethnic group to which she belongs;

2) that where the woman has her face covered, ruypōs, even at home, except before her husband and her children. This is the case in very traditional families because of the position or the functions of the head of the family. It is in particular the case of the religious personages, mola, the qāzi judges, and of a few fanatics who find it to be in good taste to adopt a more strict attitude than that recommended by traditional islam. This attitude, without being criticised openly, is scarcely appreciated by the largest number of tolerant peasants.
The third term, which is a recent creation, is not at all on the same level as the preceding ones and bears witness to a new fact connected to the new socioeconomic conditions which found their origin in Kaboul only about fifteen years ago. For reasons connected essentially to the economic development encouraged by the authorities, ${ }^{27}$ the women were authorised to go into the street with a bare face, ruyloč, that is, without wearing the large veil, čâdari A BD 162 which covers them from head to foot. In the following years this measure had as a consequence a considerable increase of the number of čadari on sale as bargains in the bazaars of Kaboul and has caused their prices to fall. Important categories of urban and rural Afghans have thus been able to acquire a čàdari at a good price (50 Afghanis = less than a dollar, instead of 500 Afghanis), although the social or ethnic group to which they belong had not had the custom of wearing them (Hazāra, Köhestäni, Lögari, and, in general, many of the rural inhabitants and even the nomads). It is the same in Sotol as elsewhere: the women have received from their husbands a $\check{c} \bar{a} d a r i$, the wearing of which is less the sign of a conservative attitude than that of a social condition above middle class. It is thus natural that one felt the need to give a designation to this new group of women, who, leaving the house where they are either ruygir, unveiled, or ruypōs, wearing a head-veil, put on a čádari; for this a new term was necessary: it is thus that one formed analogically the word ruypot, with a hidden face. This term is not opposed to the other two, it expresses very simply a new reality: in place of wearing the head-veil, ruyband, costing from 20 to 50 Afghanis, which every woman has for leaving the house and that a few even put on at home (the ruypōs women), this new category of ruypot women wear, when leaving, the complete veil, ćädari, costing from 100 to $500 \mathrm{~A}$ fghanis. Thus, whether one is ruygir or ruypōs at home, one is often ruypot when leaving the house to go visiting, to go on a trip, but never when going to work, assuming, of course, that the financial situation of their husbands permits this.

It follows from this that the Parāči speakers like the Persian-speakers of the valley of Sotol are following the destiny (normal from a certain viewpoint) of the Afghan countryside which, for the moment, is going to become sunken in a "related" tradition at the very moment when the capital is evolving towards a new norm marked by modern tendencies. Thus the difference of the attitude of the city and of the countryside towards "progress" is inscribed in words.

b) Sometimes minor peculiarities of vocabulary carry interesting 
information about the material culture. This is the case with the two "words meaning both "gloves": deskaś and dezbela.

Deskias $(=*$ dest- "hand" + -kaš, radical of the verb kašidan "draw", kb and prs id.) is woolen. par. pōci, prs. pašmi "knitted". It guarantees protection against cold: thus one always has a pair.

Dezbèla $(=*$ dest-" hand" + -be $l$ - "spade" + derivational suffix $-a)$ is in leather, par. and prs. carmi. One only wears it on the left hand, for the harvest, to protect it against thorns, while the right hand hoids the sickle. This word is not known either in kb. or in prs.

The use of the latter glove is revealing of a state of things which is not unrelated to the impending disappearance of par. It indicates that the grain is overloaded with thorns, which sometimes considerably lessen the yield of the already thankless land and are added to diverse factors causing serious difficulties for the mountainous agriculture of the Pärači (lack of labor, destruction of the terrasses, price of seed, of feed, etc.).

All of this vocabulary is in large part Käboli and thus shows an external origin, "foreign" like the object or the custom. In wearing a čndari, a complete veil, the Parăči ladies are imitating the u.:il-to-do bourgeosie of $\ddot{C}$ arikär and of Kaboul. If the gloves against tin: cold or against the thorns bear the káboli or, in any case, Persian names, it is because they are not or are no longer made in the valley of $\breve{S} o t o l$. But here and there an authentic Parä $\check{c} i$ word emerges, which puts us on the path of antique traditions for the most part extinguished.

CONCLUSIONS

In a general way, true mutations or, at least, disruptions of equilibrium taking place in the sociocultural situation, are in the process of causing an upheaval with respect to the status of the tribal language of the $\bar{O}$ rmur and the Parä $\breve{c} i$ so that its yield is regressing to the point that its very existence is called into question. Now this fact has as a corollary the threatening of the ethnic identity of these multilingual groups. When one speaks the language of another, one ends up, in A fghanistan, letting oneself be assimilated and even taking back the "nationality" of the other. We know quite well these Paṣtun, these Torkmen, and these Arabs speaking Persian who are on the way to dissolving into an ethnic group of adoption. But each time an important change was necessary, an up- heaval had taken place in their conditions of living and of work. To continue to speak his tribal language and not identify himself with the Persian speakers or the Paștó speakers in the neighboring area, it is necessary for one to be motivated when one is only a minority group. The best motivation to remember, to remain what one is, still rests in the immediate interest of the majority. When one is interested in speaking another language, clearly more profitable economically and intellectually, one is also interested in becoming someone else and in finding more advantageous living space. It is thus vain to defend a language and an ethnic status which would only be old-fashioned folklore.

The $\bar{O}$ rmurs have forgotten their geographic origin, the region which at one moment of their history constituted the epicenter from which their ethnic group propagated itself, or which formed a domain where their tribal language had the status of a common language. They renounced the religious traditions which distinguished them from the neighboring ethnic groups and gave their idiom the prerogative of a secret language. Finally, attacked by the imperatives of economic and industrial development, they had no choice but to rejoin the ranks of the Paștun or the Tajek who possess the land, control the bazaars, and occupy the key posts in administration.

Among the Parāči the changes which took place in the ideological order of religious beliefs and of ethnics as a result of islamisation, affected the language without it being, for a long time, truly placed in danger. The isolation which protected them from the intrusion of the common languages has, however, been nibbled away to the extent that political unification of the country undertaken by Emir < Abdur Rahmān (1885-1901) progressed. The construction of roads and required military service have recently struck a fatal blow to this refuge area: one entered among the Parăči and they left their valleys open from then on. The economic and industrial development did the rest: not only did it create new needs, disturb the traditional net of points of selling and buying. break the equilibrium of the prices of agricultural and industrial products, but it also dismantled once and for all the self-sufficiency and the mountain economy in drawing into the factories and the towns an irreplaceable labor.

The $\bar{O}$ rmurs, in forgetting their own interests, and the Paräcis, in leaving their valleys, try to resolve, each in their own way, the problem which "progress" poses for them. They are doing it at the price of their identity, but would there be any other end? 
SUMMARY

On the Iranian plateau, as at numerous other points of the globe, we are today witnessing a progressive reduction of linguistic diversity. Economic growth, political unification and various concomitant evolutionary phenomena bring about the elimination of languages which have ceased being or have not succeeded in becoming common, national, or official languages.

The confines of this article do not permit studying this process as a whole, nor in all the points at which it manifests itself. We content ourselves with describing - and in so far as possible analyzing - the situation of Ormuri and of Parăči, the two relict languages of the Southeast Iranian plateau to which we have dedicated numerous investigations and voluminous studies in the course of the last ten years. G. Morgenstierne, their discoverer, had made a grammatical description of them as early as 1929 (Indo-Iranian Frontier Languages, Vol. 1). We have pursued his efforts and present here on the one hand the sociocultural framework of each of these languages and on the other hand an analysis of the process of disappearance in which each of them is engaged in its own way. For this we have brought together all the information known concerning their past, their present situation and their probable future as indicated by the sociocultural profile of the two plurilingual groups destined to lose their ethnic identity in the near future.

The reasons for the approaching death of these two languages are analyzed very concretely in each of the points where they are still spoken. On the other hand, on the dialectological level we bring out the "marks" heralding this disappearance.

Berne

\section{NOTES}

We are indebted to G. Fussman (Strasbourg) and to G. Redard (Berne) for reading over our manuscript and for giving us useful comments. English translation by L. Jenkins (Vienna).

1. See G. Morgenstierne: Report on a linguistic mission to Afghanistan, Oslo 1926: 39-69, Report on a linguistic mission 10 North-Western India, Oslo 1932, 64-67, Irano-Dardica, Report on a linguistic mission to North-Western India, Oslo 1932, 64-67, Irano-Dardica, Wiesbaden 1973: 327-343; G. Fussman: Atlas linguistique des parlers dardes et kafirs,
I. Cartes, II. Commentaire, Paris 1972 (see II. pp. XIII-XVI: Bibliographie, pp. 11-33: Présentation des languages dardes et kafires). For the culture see G. S. Robertson: The Kafirs of the Hindu-Kush, London 1896. A. G. Aslanov et al., The
Kafirs (Nuristanis), in G. Grassmuck - L. W. Adamec - F. H. Irwin (Eds.): Afgahanistan. Some New Approaches, Ann Arbor 1969: 54-67. Cultures of the Hindukush, passim.

2. Morgenstierne: Reports (see note 1); Indo Iranian Frontier Languages III. The Pashai Language, 1. Grammar, Oslo 1967 (2nd edition 1973), 2. Texts and translations, Oslo 1944 (2nd ed. 1973), 3. Vocabulary, Oslo 1956 (2nd ed. 1973); Irano-Dardica, pp. 231-272, 373-380; G. Buddruss: Beiträge zur Kenntnis der Pašai-Dialekte, Wiesbaden 1959 (Abh. für die Kunde des Morgenlandes 33, 2); Fussman (see note 1); P. Snoy: Bagrot, Eine dardische Talschaft im Karakorum, Graz 1975.

3. See G. Morgenstierne: Indo-Iranian Frontier Languages I, Orrmuri, pp. $305-415$ and 428; 'Supplementary notes on $\bar{O}$ muri', in Norsk Tidsskrift for Sprogvidenskap, 5, Oslo 1932: 5-36; Ch. M. Kieffer: L'Ōmuri, 1. Grammaire, 2. Textes, 3. Lexique phraseologique (to appear).

4. V. G. Morgenstierne: IIFL I, Parachi, pp. 1-304 and 417-428; - Ch. M. Kieffer: Parači 1973 (to appear)

5. V. G. Redard: 'Panorama linguistique de l'Iran', in Asiatische Studien 1-4 (1954): 137-148.

6. This is a political concept created by the Afghans demanding a revision of the "Durand line", that is of the Afghan-Pakistan border. It designates the Pakistan Territories where the Pašto-speakers live and constitutes, consequently, a term particularly res where the Pasto-speakers live and constitutes, consequently, a term particularly
convenient for dialectology. See Khalil Ahmad Abawi: Der Kampf des pachtunischen Volkes um die Unabhängigkeit seiner Heimat Pachtunistan, Thesis, Freiburg in Breisgau 1962. M. Klimburg: Afganistan, Das Land im historischen Spannungsfeld Mittelasiens, Vienna 1966: 67, 69, 75-78, 82, 84-92, 116-117, 178, 207. D. Fröhlich: 'Nationalismus und Nationalstaat in Entwicklungsländern', Afghanische Studien 3, Meisenheim am Glan 1970: 206-212. W. Kraus (ed.): Afghanistan. Natur, Geschichte und Kultur, Staat, Gesellschaft und Wirtschaft. Tübingen-Basel 1972: 127-8, 132, 135, 284, 394. For the diplomatic aspect of the question, see Y. Rodrigues: La question du Pouchtounistan, Caboul 1962, Ambassade de France, 29 p. typed.

7. From the historical point of view it would be convenient to add Turan or "Outer Iran", see La civilisation iranienne (Perse, Afghanistan, Iran exterieur) Paris 1952. Iran", see

8. V. G. Redard, op. cit. (s. note 5).

9. V. H. Penzl: A Grammar of Pashto. A descriptive study of the dialect of Kandahar. Afghanistan, American Council of Learned Societies, Washington 1955. For the dialectology of Pašto, see Ch. M. Kieffer: (Atlas de l'Afghanistan). L'établissement des cartes phonetiques: première résultats, in "Arbeitspapier" 13, Universität Bern 1974: 24-33.

10. Afghan University authorities adhere to the appellation Dari lit. '(language) of the court', which one calls the Persian in use in Afghanistan, in order to distinguish it from the Persian of Iran. This appellation can suit us for the literary Persian (Publications and official letters), and for the Persian used at the University (courses ex cathedra), and on the radio (academic or conventional broadcasts). The problem is completely different, however, for the dialectologist: it is necessary to distinguish the numerous local dialects which are very diverse and all popular (Káboli, Herâti, Mazäri, Badaxš̀i, Lögari, Köhestäni, Hazäragi, the dialect of Ghör, etc), which are exceedingly different from this Dari! (Cf. also note 3 ).

11. See notes 3 and 4.

12. See Ch. M. Kieffer: Le multilinguisme des Ormurs de Baraki-Barak (Afghanistan) "Note sur les contacts de dialects: Ormuri, pašto et persan kābali", in Studia Iranica I (1972): 115-126; Grammaire (de 1"Ormuri), Introduction (to appear). 
13. Kaboli is the language of the city and region of Kabul, which is tending to become the common language of Afghanistan, no matter what the mother tongue of the speakers may be. Cl. 'Abd-ol Ghafur Farhãdi: Le persan parlé en Afghanistan, Grammaire du Käboli, accompagnée d'un recueil de quatrains populaires de la région de Käbol, Paris 1955: The spoken Dari of Afghanistan. A Grammar of Käboli Dari(Persian), compared to the literary language, Kabul 1975.

14. nåk woman: cf. ps. näwē 'the bride'; nåk 'pear' < kb. cf. Turner s.v. 7037 *nakkain the shape of a nose': many plants, fruits, vegetables, and mushrooms acquire their name from a resemblance to a part of the body.

15. See Ch. M. Kieffer $=$ Multilinguisme, p. 124.

16. Baraki-Barak, administrative seat of the province of Logar (in the 19th century it was Baraki-Rajan, $3 \mathrm{Km}$ away), is located $80 \mathrm{Km}$ to the South of Kabul. Itinerary: Kabul 5 km: Binisar 11 km: Pol-e Sang-e Nawišta, 16 km: Caräsyā, 39 km: Madäya (<Mohammad Aya), 39 km, Kolangär (bazar) 79 km: Baraki-Barak (bazar).

17. See G. Morgenstierne: Report 1926: 16-17.

18. See L'Encyclopédie de l'Islam (new French edition) I: 1155-1158 s.v. Bäyazid.

19. But not sayyed-e san-e juma lit. "Sayyed of the evening before Friday", which is a

9. But not sayyed-e san'-e juma lit. "Sayyed of the evening before Friday", which is a
derogatory surname which the Sunnites give to the Shiites. In fact, with the latter, a popular belief is current according to which the children of a family not sayyed which are born the evening before a Friday are likewise sayyed. It is a way of making fun of them and those who claim to be sayyed without their genealogy supporting this claim, are not at all rare.

20. See Encyclopédie de IIslam, s.v. Rawshàniyya.

21. See A dictionary of the Pathan tribes on the North-West frontier of India (by J. W. Murray), Calcutta 1899. 19\$10, p. 94 s.v. Turis.- O. Caroe: The Pathans, $550 / 4$ B.C. - A.D. 1957, London 1958, see Index s.v. Turis.

22. See G. Redard: Afghanistan, Zurich 1974: 65-66 (islamisation), 97-134 (economy). G. Etienne: L'Afghanistan ou les aléas de la cooperation, Paris 1972, passim.

23. The definition is first of all geographic: bordered on the north by the crest of the Hindukus, and on the West by the rift of the Aryandäb, and on the South by the Kábol river and on the East by the Konar river; it is also cultural: mountain agriculture, on terraces in the narrow part of the valley; fields and prairies in the high glacial valleys, permitting both agriculture and animal husbandry.

24. See J. Chelhod: Les structures du sacré chez les Arabes Paris 1964, passim.

25. A BD 80 . - the word means also modesty, bashfulness, virtue. See also $L$. Dupree: Afghanistan, Princeton 1973: 460, 463, 531-533, 554.

26. ABD 72 pot; pš pot Prob. from Indian.

27. See L. Dupree, op. cit., pp. 530-533 (excellent analysis of the process of suppression of the veil and of its consequences)
This paper has been shortened and translated from French into English without any possibility for the author to check the final text.

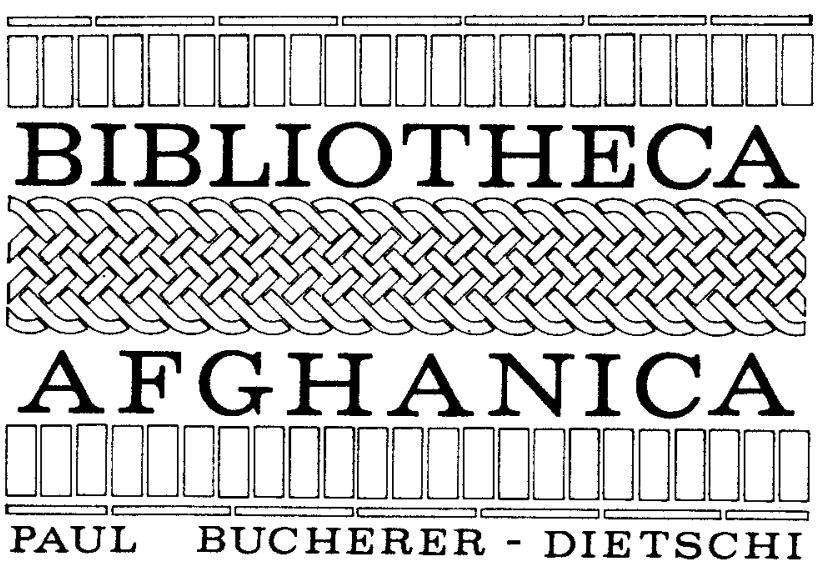

